\title{
Portfolios Effective Time Formation/Holding Period Based On Momentum Investment Strategy
}

Tov Assogbavi, Laurentian University, Canada

Bridget Leonard, Laurentian University, Canada

\begin{abstract}
This paper examines the momentum investment strategy based on past market information to evaluate performance, time formation/holding period and seasonality impact on the Canadian Market ${ }^{l}$. In doing so, we assess the effectiveness of portfolio formation and holding periods of this strategy. Utilizing variant models of different methodologies, we find strong evidence that assesses a 9 month formation and a 9 month holding period as the most effective formation/holding period in implementing a Momentum Investment Strategy when the formation period begins in January. We also find that regardless of when the formation period begins, the most effective portfolio will be held for 9 months beginning in October. While these findings confirm the short term nature of this investment strategy, they however differ in terms of the length of formation/holding periods commonly utilized in the literature. The shortness of the actual effective formation/holding periods may be caused mainly by the growing knowledgeable participants in the market. Investors who base their portfolio construction on momentum investment strategy would achieve higher returns by shortening their portfolio formation/holding periods.
\end{abstract}

\section{INTRODUCTION}

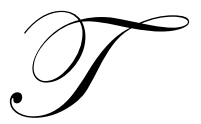

here has been a long debate and research on whether historical data on stocks is useful information in forecasting stock price changes. According to the weak form of the Efficient Market Hypothesis, it is impossible to forecast market direction based on past data. Nevertheless, many researchers, DeBondt and Thaler (1985), Jegadeesh and Titman (1993), Assogbavi, Khoury, and Yourougou (1995) Baytas and Nusret (1999), Dirk, DeBondt and Weber (1999), Mun, Vasconcellos, and Kish (2000), among others, have challenged this hypothesis by showing that investors can achieve abnormal returns using investment strategies based on past market data such as price and trading volume. Recent findings by Assogbavi et al. (2005), Chordia and Swaminathan (2000), and Gervais, Kaniel and Mingelgrin (2001), on investment strategies based on historical data tend to confirm that past stock price and trading volume provide valuable information in predicting market direction and stock returns. Accordingly, practitioners should consider using past market information in constructing investment portfolios. However, the effective portfolio time formation/holding periods may vary depending on the investment strategy utilized and the investment timeframe. For instance, while contrarian investment strategies recommend buying past losers on a 3 years formation for 2 years holding period, momentum strategies recommend buying past winners on a 12 months formation for a 9 months period. From a practitioner standpoint, knowing which time formation/holding period to apply for each of these investment strategies becomes very challenging. The objective of this paper is twofold. The first part investigates different portfolio time formation/holding periods of the momentum investment strategy based upon previous studies such as those by Jegadeesh and Titman (1993) to assess the most effective time formation/holding period on the Canadian stock market using the Toronto Stock Exchange (TSX) 60. The second part of the paper investigates the effect of seasonality on the time formation/holding periods.

\footnotetext{
${ }^{1}$ The authors acknowledge research support from CISRO Institute of Management at Laurentian University.
} 
The remainder of the paper is as follows: Section II presents a brief review of the literature; in Section III the data and methodologies are described; Section IV summarizes results and Section V indicates our conclusions.

\section{REVIEW OF LITERATURE}

Price momentum strategy postulates that stocks with high returns will continue to generate high returns, and stocks with low returns will continue to generate low returns. It attempts to exploit upward or downward trends in stock prices based on the belief that there is a momentum behind stocks that will compel prices to continue in their current direction. Rouwenhorst (1998) found that use of a momentum strategy yielded higher returns in 12 European countries between 1980 and 1995. Jegadeesh and Titman (1993) found similar results in the U.S. markets from 1965 to 1989. They determined that during this period, a momentum strategy would yield significant abnormal returns that are consistent with delayed price reactions to firm specific information but that these effects reverse in the long term. This would suggest a short term momentum strategy but a long term contrarian strategy. Cleary and Inglis (1998) also support the momentum strategy with a study based on the Canadian Market from 1978 to 1990. Chan, Hameed and Tong (1999) investigate the profitability of the momentum strategy in the global equity markets. Their results indicate evidence of statistically and economically significant profits from momentum strategies based on individual stock market indices and predominantly caused by price continuation. Assogbavi, Osagie, Frieder and Shin (2005) also found evidence to support a momentum strategy based on a study of the Canadian Market from 1990 to 2000 .

\section{DATA AND METHODOLOGY}

\section{Data Description}

The data used in this study consists of daily trading prices from January 1996 to December 2004 on 48 stocks that made up the S\&P/TSE 60 index. The S\&P/TSE 60 Index is the blue-chip benchmark for index-based products, and includes representation by all 11 sector subgroups in the TSE 300 . It includes 60 of the largest and most liquid stocks traded on the TSE. Table I below presents the stocks used in the study as well as the key statistics based on 2004 stock data.

\section{Methodology}

For comparison purposes, the methodology used in this paper to evaluate the performance of the momentum investment strategy is adapted from previous articles with minor modifications. Specifically, our methodology is based on Jegadeesh and Titman (1993). In this analysis, the original ideas and approaches are followed as closely as possible.

The momentum investment strategy assumes that stocks under-react to the arrival of new information. It suggests that one buy past winners and sell past losers. The approach used in this study is a variant of that of Jegadeesh and Titman (1993). Our empirical test results are presented in Table I.

For each test period, which includes a formation and holding period, two stock portfolios will be formed based on the cumulative returns $\mathrm{R}_{\mathrm{jt}}$ for each stock during the formation period. The formation periods will be 3, 6, 9 and 12 months and will be followed by holding periods of 3, 6, 9 and 12 months. $\mathrm{R}_{\mathrm{jt}}$ is calculated as below;

$$
R_{j t}=\frac{P_{j t L}-P_{j t F}}{P_{j t F}}
$$

Where $R_{\mathrm{jt}}=$ cumulative return in a given stock $\mathrm{j}$ for the $\mathrm{t}^{\text {th }}$ formation period;

$\mathrm{P}_{\mathrm{jtF}}=$ the price of a given stock $\mathrm{j}$ on the first day of the $\mathrm{t}^{\text {th }}$ formation period;

$\mathrm{P}_{\mathrm{jtL}}=$ the price of a given stock $\mathrm{j}$ on the last day of the $\mathrm{t}^{\text {th }}$ formation period. 
These formation period returns will then be used to determine composition of the portfolio. It will include the top $10 \%$ of the stocks. In the subsequent holding periods, the cumulative average returns of all securities in the portfolio will be calculated.

Table I

\begin{tabular}{|c|c|c|c|}
\hline \multicolumn{4}{|c|}{ Summary Statistics of Stocks (2004) } \\
\hline Company & Price 2004 & $\begin{array}{l}\text { Market } \\
\text { Capitalization (\$mil) }\end{array}$ & $\begin{array}{l}\text { Standard Deviation } \\
(1996 \text { - 2004) }\end{array}$ \\
\hline Abitibi-Consolidated Inc. & 8.28 & 4,365 & $2.27 \%$ \\
\hline Agrium Inc. & 20.27 & 2,168 & $2.08 \%$ \\
\hline Alcan Inc. & 58.85 & 19,798 & $1.96 \%$ \\
\hline ATI Technologies Inc. & 23.31 & 5,047 & $3.63 \%$ \\
\hline Bank of Montreal & 57.8 & 25,624 & $1.57 \%$ \\
\hline Bank of Nova Scotia, The & 40.89 & 34,430 & $1.94 \%$ \\
\hline Barrick Gold Corp. & 29 & 13,928 & $2.43 \%$ \\
\hline BCE Inc. & 28.97 & 24,464 & $2.43 \%$ \\
\hline Biovail Corp. & 19.8 & 3,988 & $3.35 \%$ \\
\hline Bombardier Inc. Class B SV & 2.38 & 10,182 & $2.84 \%$ \\
\hline CAE Inc. & 5.1 & 2,080 & $2.55 \%$ \\
\hline Cameco Corp. & 41.95 & 3,517 & $2.61 \%$ \\
\hline Canadian Imperial Bank of Commerce & 72.35 & 23,681 & $1.78 \%$ \\
\hline Canadian Natural Resources Ltd. & 51.39 & 10,481 & $2.07 \%$ \\
\hline Canadian Tire Corp. Ltd. Class A & 56.32 & 3,562 & $1.95 \%$ \\
\hline Cognos Inc. & 52.84 & 4,019 & $3.63 \%$ \\
\hline Cott Corp. & 29.69 & 3,034 & $3.01 \%$ \\
\hline Dofasco Inc. & 45.42 & 2,693 & $1.72 \%$ \\
\hline Domtar Inc. & 14.5 & 3,606 & $2.02 \%$ \\
\hline Enbridge Inc. & 59.76 & 9,031 & $1.32 \%$ \\
\hline Falconbridge Ltd. & 31.02 & 5,304 & $2.21 \%$ \\
\hline Husky Energy Inc. & 34.26 & 10,816 & $2.22 \%$ \\
\hline Imperial Oil Ltd. & 71.4 & 22,155 & $1.59 \%$ \\
\hline Inco Ltd. & 44.05 & 7,877 & $2.37 \%$ \\
\hline IPSCO Inc. & 57.31 & 4,900 & $2.29 \%$ \\
\hline Kinross Gold Corp. & 8.45 & 2,560 & $3.88 \%$ \\
\hline Loblaw Companies Ltd. & 72.15 & 16,812 & $1.45 \%$ \\
\hline Magna International Inc. & 99.28 & 10,126 & $1.70 \%$ \\
\hline MDS Inc. & 16.97 & 3,052 & $2.25 \%$ \\
\hline National Bank of Canada & 49.66 & 7,465 & $1.61 \%$ \\
\hline Nexen Inc. & 48.72 & 6,500 & $2.15 \%$ \\
\hline Nortel Networks Ltd. & 4.18 & 22,869 & $4.20 \%$ \\
\hline NOVA Chemicals Corp. & 56.72 & 3,040 & $2.63 \%$ \\
\hline Petro-Canada Inc. & 61.18 & 15,913 & $1.85 \%$ \\
\hline Potash Corporation of Saskatchewan Inc. & 99.75 & 6,031 & $2.12 \%$ \\
\hline Precision Drilling Corp. & 75.38 & 3,473 & $2.56 \%$ \\
\hline Quebecor World Inc. & 25.85 & 3,568 & $1.64 \%$ \\
\hline Rogers Communications Inc. Class B NV & 31.44 & 5,580 & $2.85 \%$ \\
\hline Royal Bank of Canada & 64.18 & 38,807 & $1.45 \%$ \\
\hline Shaw Communications Inc. Cl. B & 21.93 & 5,126 & $2.40 \%$ \\
\hline Suncor Energy Inc. & 42.56 & 15,368 & $1.84 \%$ \\
\hline Talisman Energy Inc. & 32.35 & 10,524 & $2.07 \%$ \\
\hline TELUS Corp. & 36.25 & 8,385 & $2.19 \%$ \\
\hline Thomson Corp., The & 42.27 & 29,051 & $1.95 \%$ \\
\hline Toronto-Dominion Bank, The & 49.99 & 28,921 & $1.77 \%$ \\
\hline TransAlta Corp. & 18.05 & 3,300 & $1.63 \%$ \\
\hline TransCanada Corporation & 29.84 & 13,351 & $1.36 \%$ \\
\hline Zarlink Semiconductor Inc. & 3.06 & 361 & $3.82 \%$ \\
\hline
\end{tabular}




\section{ANALYSIS AND RESULTS}

Table II below presents our major findings in Part 1, using formation periods beginning in January. Table II shows the returns for each portfolio formed, as well as the average return from 1996 to 2003 of each time portfolio/holding period. The results are inconsistent with the recommended momentum strategy of buying past winners on a 12 months formation for a 9 months period. It indicates instead that the highest returns can be achieved through a 9 months formation with a 9 months holding period.

\section{Table II: Summary of Returns of Momentum Strategy}

The formation of portfolios was based on past returns of stocks during the stated formation period. The 5 stocks with the highest returns during the formation period formed the portfolio. The returns of the portfolios were calculated over the subsequent holding periods of 1,2,3, and 4 quarters. For comparison purposes, the market returns were also calculated based on the return of the S\&P/TSX Composite Index over each holding period.

\begin{tabular}{|c|c|c|c|c|c|c|c|c|}
\hline \multicolumn{9}{|c|}{ Table II: Summary of Returns of Momentum Strategy - Formation Period Beginning in January } \\
\hline \multirow{4}{*}{$\begin{array}{c}\text { Holding } \\
\text { Period } \\
\text { Length }\end{array}$} & \multicolumn{8}{|c|}{ Formation Period } \\
\hline & \multicolumn{2}{|c|}{1 Quarter } & \multicolumn{2}{|c|}{2 Quarters } & \multicolumn{2}{|c|}{3 Quarters } & \multicolumn{2}{|c|}{4 Quarters } \\
\hline & \multicolumn{2}{|c|}{ January - March } & \multicolumn{2}{|c|}{ January - June } & \multicolumn{2}{|c|}{ January - September } & \multicolumn{2}{|c|}{ January - December } \\
\hline & Portfolio & Market & Portfolio & Market & Portfolio & Market & Portfolio & Market \\
\hline 1 Quarter & $2.03 \%$ & $3.66 \%$ & $-6.25 \%$ & $-3.03 \%$ & $8.80 \%$ & $7.94 \%$ & $11.68 \%$ & $2.10 \%$ \\
\hline 2 Quarters & $-4.00 \%$ & $1.05 \%$ & $0.31 \%$ & $4.21 \%$ & $28.35 \%$ & $10.65 \%$ & $7.55 \%$ & $5.48 \%$ \\
\hline 3 Quarters & $0.55 \%$ & $8.38 \%$ & $13.77 \%$ & $7.03 \%$ & $29.20 \%$ & $14.52 \%$ & $0.85 \%$ & $2.22 \%$ \\
\hline 4 Quarters & $17.04 \%$ & $11.50 \%$ & $17.44 \%$ & $10.68 \%$ & $15.66 \%$ & $11.69 \%$ & $5.90 \%$ & $8.59 \%$ \\
\hline
\end{tabular}

Part 2 evaluates the effect of seasonality on time formation/holding periods, where the start dates for portfolio formation begin in April, July and October. Our major findings are presented in Tables III, IV and V. Table III below shows the returns for each portfolio formed, as well as the average return from 1996 to 2003 of each time portfolio/holding period where the formation period began in April. The results indicate instead that when beginning portfolio formation in April (the second quarter of the year), the highest returns can be achieved through a 6 months formation with a 9 months holding period.

\section{Table III: Summary of Returns of Momentum Strategy}

The formation of portfolios was based on past returns of stocks during the stated formation period. The 5 stocks with the highest returns during the formation period formed the portfolio. The returns of the portfolios were calculated over the subsequent holding periods of 1,2, 3, and 4 quarters. For comparison purposes, the market returns were also calculated based on the return of the S\&P/TSX Composite Index over each holding period.

\begin{tabular}{|c|c|c|c|c|c|c|c|c|}
\hline \multicolumn{9}{|c|}{ Table III: Summary of Returns of Momentum Strategy - Formation Period Beginning in April } \\
\hline \multirow{4}{*}{$\begin{array}{c}\text { Holding } \\
\text { Period } \\
\text { Length } \\
\end{array}$} & \multicolumn{8}{|c|}{ Formation Period } \\
\hline & \multirow{2}{*}{\multicolumn{2}{|c|}{$\begin{array}{c}\text { Quarter } \\
\text { April - June } \\
\end{array}$}} & \multirow{2}{*}{\multicolumn{2}{|c|}{$\begin{array}{c}\text { 2 Quarters } \\
\text { April - September } \\
\end{array}$}} & \multirow{2}{*}{\multicolumn{2}{|c|}{$\begin{array}{c}3 \text { Quarters } \\
\text { April - December } \\
\end{array}$}} & \multirow{2}{*}{\multicolumn{2}{|c|}{$\begin{array}{c}4 \text { Quarters } \\
\text { April - March } \\
\end{array}$}} \\
\hline & & & & & & & & \\
\hline & Portfolio & Market & Portfolio & Market & Portfolio & Market & Portfolio & Market \\
\hline 1 Quarter & $-3.67 \%$ & $-3.03 \%$ & $7.94 \%$ & $7.93 \%$ & $16.67 \%$ & $2.10 \%$ & $-1.57 \%$ & $2.66 \%$ \\
\hline 2 Quarters & $3.88 \%$ & $4.21 \%$ & $27.02 \%$ & $10.65 \%$ & $12.20 \%$ & $5.48 \%$ & $-6.04 \%$ & $-1.38 \%$ \\
\hline 3 Quarters & $18.50 \%$ & $7.03 \%$ & $28.74 \%$ & $14.52 \%$ & $8.48 \%$ & $2.21 \%$ & $0.75 \%$ & $5.10 \%$ \\
\hline 4 Quarters & $23.28 \%$ & $10.67 \%$ & $18.23 \%$ & $11.68 \%$ & $9.83 \%$ & $8.59 \%$ & $15.98 \%$ & $7.75 \%$ \\
\hline
\end{tabular}

Table IV below shows the returns for each portfolio formed, as well as the average return from 1996 to 2003 of each time portfolio/holding period where the formation period began in July (the third quarter). For a third 
time, the results propose a shorter formation period than is traditionally recommended. The results indicate that when beginning portfolio formation in July (the third quarter of the year), the highest returns can be achieved through a 3 months formation with a 9 months holding period.

\section{Table IV: Summary of Returns of Momentum Strategy}

The formation of portfolios was based on past returns of stocks during the stated formation period. The 5 stocks with the highest returns during the formation period formed the portfolio. The returns of the portfolios were calculated over the subsequent holding periods of 1, 2, 3, and 4 quarters. For comparison purposes, the market returns were also calculated based on the return of the S\&P/TSX Composite Index over each holding period.

\begin{tabular}{|c|c|c|c|c|c|c|c|c|}
\hline \multicolumn{9}{|c|}{ Table IV: Summary of Returns of Momentum Strategy - Formation Period Beginning in July } \\
\hline \multirow{4}{*}{$\begin{array}{l}\text { Holding Period } \\
\text { Length }\end{array}$} & \multicolumn{8}{|c|}{ Formation Period } \\
\hline & \multicolumn{2}{|c|}{1 Quarter } & \multicolumn{2}{|c|}{2 Quarters } & \multicolumn{2}{|c|}{3 Quarters } & \multicolumn{2}{|c|}{4 Quarters } \\
\hline & \multicolumn{2}{|c|}{ July - September } & \multicolumn{2}{|c|}{ July - December } & \multicolumn{2}{|c|}{ July - March } & \multicolumn{2}{|c|}{ July - June } \\
\hline & Portfolio & Market & Portfolio & Market & Portfolio & Market & Portfolio & Market \\
\hline 1 Quarter & $6.73 \%$ & $7.93 \%$ & $8.15 \%$ & $2.10 \%$ & $-0.01 \%$ & $2.66 \%$ & $-7.64 \%$ & $-4.42 \%$ \\
\hline 2 Quarters & $24.54 \%$ & $10.65 \%$ & $4.35 \%$ & $5.48 \%$ & $-4.95 \%$ & $-1.38 \%$ & $-0.16 \%$ & $2.13 \%$ \\
\hline 3 Quarters & $27.75 \%$ & $14.52 \%$ & $0.53 \%$ & $2.21 \%$ & $1.75 \%$ & $5.10 \%$ & $5.72 \%$ & $4.53 \%$ \\
\hline 4 Quarters & $19.01 \%$ & $11.68 \%$ & $3.72 \%$ & $8.59 \%$ & $8.86 \%$ & $7.75 \%$ & $5.58 \%$ & $8.70 \%$ \\
\hline
\end{tabular}

Table V below shows the returns for each portfolio formed, as well as the average return from 1996 to 2003 of each time portfolio/holding period where the formation period began in October (the fourth quarter). When beginning portfolio formation in the last quarter of the year, the results are quite consistent with traditional recommendations for portfolio formation/holding period time. In this instance, the highest returns can be achieved through a 12 months formation with a 9 months holding period.

\section{Table V: Summary of Returns of Momentum Strategy}

The formation of portfolios was based on past returns of stocks during the stated formation period. The 5 stocks with the highest returns during the formation period formed the portfolio. The returns of the portfolios were calculated over the subsequent holding periods of 1,2,3, and 4 quarters. For comparison purposes, the market returns were also calculated based on the return of the S\&P/TSX Composite Index over each holding period.

\begin{tabular}{|c|c|c|c|c|c|c|c|c|}
\hline \multicolumn{9}{|c|}{ Table V: Summary of Returns of Momentum Strategy - Formation Period Beginning in October } \\
\hline \multirow{4}{*}{$\begin{array}{c}\text { Holding } \\
\text { Period Length }\end{array}$} & \multicolumn{8}{|c|}{ Formation Period } \\
\hline & \multirow{2}{*}{\multicolumn{2}{|c|}{$\begin{array}{c}1 \text { Quarter } \\
\text { October - December }\end{array}$}} & \multirow{2}{*}{\multicolumn{2}{|c|}{$\begin{array}{c}2 \text { Quarters } \\
\text { October - March }\end{array}$}} & \multirow{2}{*}{\multicolumn{2}{|c|}{$\begin{array}{c}\text { 3 Quarters } \\
\text { October - June }\end{array}$}} & \multicolumn{2}{|c|}{4 Quarters } \\
\hline & & & & & & & October & ptember \\
\hline & Portfolio & Market & Portfolio & Market & Portfolio & Market & Portfolio & Market \\
\hline 1 Quarter & $11.69 \%$ & $2.10 \%$ & $-3.10 \%$ & $2.66 \%$ & $-11.53 \%$ & $-4.42 \%$ & $3.01 \%$ & $7.46 \%$ \\
\hline 2 Quarters & $8.73 \%$ & $5.48 \%$ & $-11.23 \%$ & $-1.38 \%$ & $-3.26 \%$ & $2.13 \%$ & $14.07 \%$ & $9.79 \%$ \\
\hline 3 Quarters & $6.82 \%$ & $2.21 \%$ & $-5.29 \%$ & $5.10 \%$ & $10.01 \%$ & $4.53 \%$ & $15.80 \%$ & $14.21 \%$ \\
\hline 4 Quarters & $14.90 \%$ & $8.59 \%$ & $7.70 \%$ & $7.75 \%$ & $7.92 \%$ & $8.70 \%$ & $7.16 \%$ & $10.66 \%$ \\
\hline
\end{tabular}

\begin{tabular}{|c|c|c|c|c|}
\hline \multicolumn{2}{|c|}{ Table VI: Summary of Optimum Formation/Holding Time Periods } \\
\hline Formation Period & Length & Holding Period & Length & Average Return \\
\hline January - August & 3 Quarters & October - June & 3 Quarters & $29.20 \%$ \\
\hline April - August & 2 Quarters & October - June & 3 Quarters & $28.74 \%$ \\
\hline July - August & 1 Quarter & October - June & 3 Quarters & $27.75 \%$ \\
\hline October - August & 4 Quarters & October - June & 3 Quarters & $15.80 \%$ \\
\hline
\end{tabular}

* Notice that the optimum formation periods all end in August with optimum holding periods all ending in June. 


\begin{tabular}{|l|c|c|c|c|c|}
\hline \multicolumn{2}{|c|}{ Momentum Performance Comparison with Stock Index Performance } \\
\hline \multicolumn{2}{|c|}{} & $\begin{array}{c}\text { 1 Quarter } \\
\text { Holding }\end{array}$ & $\begin{array}{c}\text { 2 Quarters } \\
\text { Holding }\end{array}$ & $\begin{array}{c}\text { 3 Quarters } \\
\text { Holding }\end{array}$ & $\begin{array}{c}\text { 4 Quarters } \\
\text { Holding }\end{array}$ \\
\hline \multirow{2}{*}{$\begin{array}{l}\text { Formation Periods } \\
\text { starting in January }\end{array}$} & Mean & $4.07 \%$ & $8.05 \%$ & $11.09 \%$ & $14.01 \%$ \\
\cline { 2 - 6 } $\begin{array}{l}\text { Formation Periods } \\
\text { starting in April }\end{array}$ & Mest & 0.649 & 0.573 & 0.597 & 0.607 \\
\cline { 2 - 6 } $\begin{array}{l}\text { Formation Periods } \\
\text { starting in July }\end{array}$ & T Test & $5.05 \%$ & $9.76 \%$ & $14.55 \%$ & $16.86 \%$ \\
\hline $\begin{array}{l}\text { Formation Periods } \\
\text { starting in October }\end{array}$ & T Test & 0.413 & 0.309 & 0.187 & 0.271 \\
\cline { 2 - 6 } & Mean & $0.18 \%$ & $6.51 \%$ & $9.29 \%$ & $9.43 \%$ \\
\hline
\end{tabular}

\section{CONCLUSIONS}

This study attempts to produce a better understanding of the momentum investment strategy and the impact of seasonality on returns. It is consistent with past research in that overall, use of the momentum strategy will generate higher returns. The highest returns from use of this strategy during the 1996 to 2004 period in the Canadian Market stem from a 9 months holding period when the formation period ends in September, regardless of when the formation period begins. Thus holding the portfolio from October to June appears to be more important than forming the portfolio for 3, 6, 9 or 12 months.

\section{REFERENCES}

1. Assogbavi, Osagie, Frieder and Shin, 2005, Investment Strategies, Performance and Trading Information Impact, International Business and Economics Research Journal, vol. 4, no. 9

2. Assogbavi, T., N. Khoury, and P. Yourougou, 1995, Short Interest and The Asymmetry of the PriceVolume Relationship in the Canadian Stock Market, Journal of Banking And Finance 19, 1341-1358.

3. Basu, S., Investment Performance of Common Stocks in Relation to Their Price-Earnings Ratios: A Test of the Efficient Market Hypothesis. Journal of Finance 3 (June 1977), 663-82.

4. Baytas, A., C. Nusret, 1999, Do Market Overact: International Evidence, Journal of Banking \& Finance, July. 1999, vol.23 no.7 p1121-1144.

5. Campbell, J. Y., S. J. Grossman, and J. Wang, 1993, Trading Volume and Serial Correlation in Stock Returns, Quarterly Journal of Economies 108, 905 940.

6. Chan Kaloc, Allaudeen Hameed, Wilson Tong, 1999, Profitability of Momentum Strategies in the International Equity Markets, Working Paper, Hong Kong University of Science \& Technology

7. Chordia, T., and B. Swaminathan, 2000, Trading Volume and Cross-Autocorrelations in Stock Returns, Journal of Finance, Vol. IV, No 2, April 2000, 913-935.

8. Cleary, Sean, Michael Inglis, 1998, Momentum in Canadian Stock Returns, Canadian Journal of Administrative Sciences (Revue Canadienne des Sciences de l'Administration), Montreal; Sep 1998; Vol. 15, Issue. 3; pg. 279, 13 pgs.

9. Conrad, Hameed, and Niden, 1994, Volume and Autocovariances in Short Horizon Individual Security Returns, Journal of Finance 49, 1305-1329.

10. Dirk, S., W. DeBondt, and M. Weber, 1999, Contrarian and Momentum Strategies in Germany, Financial Analysts Journal 1999 Nov/Dec p104-116.

11. Gervais, S., R. Kaniel and D. Mingelgrin, 2001, The High-Volume Return Premium, Journal of Finance, Vol. LVI, No. 3, June 2001.

12. Lee, C., and B. Swaminathan, 2000, Price Momentum and Trading Volume, Journal of Finance, Vol. V, No 5, Oct. 2000, 2017-2069.

13. Lehmann, Bruce N., 1990, Fads, Martingales, and Market Efficiency, Quarterly Journal of Economics 105, $1-28$.

14. Mayshar, Joram, 1983, On Divergence of Opinion and Imperfections in Capital Markets, American Economic Review 73, 114-128. 
15. Merton, Robert C., 1987, A Simple Model of Capital Market Equilibrium with Incomplete Information, Journal of Finance 42, 483-510.

16. Mun, J.C., G.M. Vasconcellos, R. Kish, 2000, The Contrarian/Overreaction Hypothesis: An Analysis of the US and Canadian Stock Markets, Global Finance Journal 11 (2000) 53-72.

17. Narasimhan, Jegadeesh, Sheridan Titman, 1993, Returns to Buying Winners and Selling Losers: Implications for Stock Market Efficiency, Journal of Finance, Mar.1993 p65-h91.

18. Rouwenhorst, K. G., 1999, Local Return factors and Turnover in Emerging Stock Markets, The Journal of Finance, Cambridge; Aug 1999; Vol. 54, Issue 4; pg. 1439, 26 pgs.

19. Rouwenhorst, K.G., 1998, International Momentum Strategies, Journal of Finance, 53, 267-284.

20. Ying, Charles C., 1966, Stock Market Prices and Volumes of Sales, Econometrica 34, 676-685. 
NOTES 